\title{
Формирование институциональных условий предпринимательства мелиоративно- водохозяйственного комплекса аграрной сферы в регионе
}

\section{Валерий Носовский, Данил Приходько, Алина Султанова}

Дальневосточный федеральный университет, г. Владивосток, Россия

\author{
Информация о статье \\ Поступила в редакцию: \\ 20.03.2019 \\ Принята \\ к опубликованию: \\ 26.09.2019 \\ УДК 332.68:63(571.63) \\ JEL I23, I29
}

\section{Ключевые слова:}

Приморский край, институциональное предпринимательство, социальноинженерные, водохозяйственные системы, малые предприятия, трудовая занятость, организационная структура, механизм изменения институтов

\section{Keywords:}

Primorsky region, institutional entrepreneurship, sustainable development, rural areas, socio-engineering, rice-growing systems, small enterprise, productive labor, organization structure, mechanism alteration a law

\begin{abstract}
Аннотация
В работе рассмотрены вопросы общественного труда $и$ влияния институциионального предпринимательства на экономику воспроизводственных процессов. Предложены новый инновационный подход к оценке возможностей предпринимательства на основе сочиально-инженерного развития территории с учетом отраслевой идентичности, а также организационная модель и структура управленческого консультирования.

Выделены группь однородных (muповых) территорий агломерационной, индустриально-промымленной и аграрноиндустриальной направленности. Определена существенность возможностей повычения доходов консолидированного бюджета и объемов экономической деятельности. Обоснован механизм предпринимательства межрегионального государственно-частного партнерства в аграрной сфере региона.
\end{abstract}

Formation of Institutional Conditions for Entrepreneurship Land Reclamation-Agrarian Complex in the Region

Valery Nosovsky, Danil Prikhodko, Alina Sultanova

\section{Abstract}

The study examined the issues of social labor and the impact of entrepreneurship on the economy of reproduction processes based on institutional theory. Analyzed business activities in the existing municipal areas of the region, as well as urban districts. The importance of entrepreneurship in the structure of employment in the region is determined and the role of entrepreneurship in the development of Primorsky Krai is revealed.

A new innovative approach to assessing business opportunities based on social and engineering development of the territory, considering industry identity, as well as an organizational model and structure of management consulting, taking into account existing programs aimed at maintaining and developing

DOI: https://dx.doi.org/10.24866/2311-2271/2019-3/126-140 
entrepreneurship at both federal and regional levels, are proposed. The groups of homogeneous (typical) territories of agglomeration, industrial-industrial and agrarian-industrial orientation are identified. The materiality of opportunities to increase revenues of the consolidated budget and the volume of economic activity has been determined. It is proposed to organize an interregional water management center for entrepreneurship. The mechanism of entrepreneurship of interregional public-private partnership in the agricultural sector of the region is substantiated. The main purpose of the center is information, legal and scientific support and provision of services, as well as investment in reconstruction and construction projects, social engineering development with the participation of public-private partnership of Primorsky Krai. In addition, according to the results of the study, it is proposed to develop an investment infrastructure project for integrated prospective land development and reconstruction of land-reclamation facilities until 2030-2035. and the institutional mechanism of institutional entrepreneurship of the water management complex of the agrarian sector of the Primorsky Territory.

Представители политической экономии определили, что «предприниматель является всеобщим распределителем богатства: он выплачивает рабочим заработную плату, капиталисту (денежному) - ссудный процент, земельному собственнику - ренту» [1]. Установлено, что цель капиталистического способа производства - прибавочная стоимость, а не продукт. Обращено внимание на нелепость взглядов на заработную плату как аванс работнику и прибыль как премию за риск. В конечном счете, выявлено, что производительность капитала состоит в принуждении к прибавочному труду (к большему количеству труда, чем необходимо) для удовлетворения своих потребностей. Капитал и труд не обмениваются услугами. Общественное развитие труда (разделение труда), технический прогресс, наука и силы природы принимают вид производительных сил капитала. Производителен тот труд, который создает прибавочную стоимость для собственника условий производства, а «простой» непосредственный обмен денег на труд не превращает деньги в капитал [1].

Монетарная система, предполагая получение прибыли «не внутри страны, а только в обмене с другими странами», находит свое выражение в торговом балансе и до сих пор доминирует. Налоги, ставки кредита, курсы валюты и инфляция являются основными регуляторами экономики. Но обмен денег на труд без прибыли для собственника условий производства не превращает их в капитал.

Институциональная теория рассматривает роль институтов (законов, соглашений, кодексов и традиций поведения и т.п.), влияния защищенных прав собственности на эффективность производства и зависимость развития экономики от сложившихся условий формальной и неформальной деятельности [2].

Под институциональным предпринимательством понимаются коллективные действия группы людей, посредством сотрудничества и конкуренции, трансформации институтов власти, деятельность субъектов заинтересованных в решении вопросов и использующих всевозможные ресурсы, политический процесс в борьбе за власть между участниками в конкретной сфере, полномочия с возможностью реализации собственных интересов.

Институциональное предпринимательство создает новые или наделяет полномочиями уже существующие институты. Появляются они, когда организованная группа субъектов с определенным набором ресурсов реализует свои собственные интересы [3]. Общая методология включает количественные исследования и полевые методы (интервью, опросы и т. д.) на основании вырабатываемых критериев [4]. Предлагаются различные стадии продвижения иници- 
атив: постановка проблемы, мобилизация ресурсов и сопровождение принятого решения. Полевые методы включают узкоотраслевые (разработка стандартов организации) и отраслевые (социально-инженерные, водохозяйственные системы и т.д.) кейсы. На этапе подготовки участвуют предприниматели и инициаторы, которые определяют задачи институциональных изменений, а также задействованные лица и организации, которые приводят необходимые доказательства. Из внешних условий устанавливают степень заинтересованности субъектов в создании благоприятного механизма. Из внутренних - формируют экспертную группу, анализируют организационные структуры управления и актуализацию стратегии их развития. На стадии мобилизации подключаются участники (акторы) конкурентов, агентов с определенными действиями заинтересованных сторон во внешней и внутренней среде. На завершающем этапе сопровождения происходит закрепление действий по созданию отраслевой идентичности изменений с учетом национальной безопасности, стратегических задач институциональных преобразований. Учитываются практикоориентированный характер, комплексный подход и тренды (динамика) развития основных сфер (отраслей) производственной деятельности [5].

В динамике по Приморскому краю численность индивидуальных предпринимателей (далее - ИП) в 2015 г. снизалась, а малых предприятий (далее МП) - возросла (табл. 1, 2). Рост производительности труда работников МП составил 4,8 млн руб. а ИП - 1,7 млн руб.

Таблииа 1

Показатели деятельности индивидуальных предпринимателей Приморского края

\begin{tabular}{|c|l|c|c|c|}
\hline \multirow{2}{*}{ o } & \multicolumn{1}{|c|}{ Показатели } & $\mathbf{2 0 1 0}$ г. & $\mathbf{2 0 1 5}$ г. & $\begin{array}{c}\mathbf{2 0 1 5} \text { г. } \\
\text { к 2010 г. }\end{array}$ \\
\hline 1 & Численность ИП, ед. & 45807 & 42469 & 92,7 \\
\hline 2 & Численность занятых в сфере ИП, чел. & 94311 & 92580 & 98,2 \\
\hline 3 & $\begin{array}{l}\text { Выручка от реализации товаров (работ, услуг), } \\
\text { млн руб. }\end{array}$ & 91185,4 & 155192,4 & $1,7 \mathrm{p}$. \\
\hline 4 & Средняя численность занятых на 1 ИП, чел. & 2,06 & 2,2 & 106,8 \\
\hline 5 & Средний объем выручки ИП, млн руб. & 1,99 & 3,65 & 1,8 p. \\
\hline 6 & $\begin{array}{l}\text { Производительность труда работников, млн } \\
\text { руб./чел. }\end{array}$ & 0,97 & 1,68 & $1,7 \mathrm{p}$. \\
\hline
\end{tabular}

Источник: составлено авторами на основе [5]

Таблийа 2

Показатели деятельности малых предприятий Приморского края

\begin{tabular}{|c|l|c|c|c|}
\hline \multicolumn{1}{|c|}{ Показатели деятельности мальх предприятий Приморского края } \\
\hline \multicolumn{1}{|c|}{ Показатели } & $\mathbf{2 0 1 0}$ г. & $\mathbf{2 0 1 5}$ г. & $\begin{array}{c}\mathbf{2 0 1 5} \text { г. } \\
\mathbf{2 0 1 0}\end{array}$ \\
\hline 1 & \multicolumn{1}{|c|}{ Численность предприятий, ед. } & 29627 & 38778 & 130,9 \\
\hline 2 & Число замещенных рабочих мест, чел. & 174426 & 165633 & 95,0 \\
\hline 3 & $\begin{array}{l}\text { Выручка от реализации товаров (работ, услуг), } \\
\text { млн руб. }\end{array}$ & 304961,5 & 792727,3 & $2,6 \mathrm{p}$. \\
\hline 4 & $\begin{array}{l}\text { Среднее количество рабочих мест на пред- } \\
\text { приятии, ед. }\end{array}$ & 5,9 & 4,3 & 72,9 \\
\hline 5 & Средний объем выручки предприятия, млн руб. & 10,3 & 20,4 & $2,0 \mathrm{p}$. \\
\hline 6 & $\begin{array}{l}\text { Производительность труда работников, млн } \\
\text { руб./чел. }\end{array}$ & 1,75 & 4,79 & $2,7 \mathrm{p}$. \\
\hline
\end{tabular}

Источник: составлено авторами на основе [5] 
Индивидуальные предприниматели практически не вкладывают средства в свое развитие, а размер инвестиций МП не представляется существенным (табл. 3).

Таблииа 3

Показатели деятельности индивидуальных предпринимателей и мальх предприятий Приморского края

\begin{tabular}{|c|c|c|c|c|}
\hline № & Показатели & ИП & МП & $\begin{array}{c}\text { МП } \\
\text { к ИП, \% (р.) }\end{array}$ \\
\hline \multirow{3}{*}{1.} & Основные фонды, млн руб. & 21824,5 & 83627,7 & $3,8 \mathrm{p}$ \\
\hline & - на 1 предприятие или предпринимателя, млн руб. & 0,51 & 2,2 & $4,3 \mathrm{p}$. \\
\hline & $\begin{array}{l}\text { - на } 1 \text { рабочее место или занятого в сфере ИП, млн } \\
\text { руб. }\end{array}$ & 0,24 & 0,5 & $2,1 \mathrm{p}$. \\
\hline \multirow{3}{*}{2.} & Инвестиции в основной капитал, млн руб. & 2123,4 & 14347,86 & $6,8 \mathrm{p}$. \\
\hline & - на 1 предприятие или предпринимателя, млн руб. & 0,05 & 0,37 & $7,4 \mathrm{p}$. \\
\hline & $\begin{array}{l}\text { - на } 1 \text { рабочее место или занятого в сфере ИП, млн } \\
\text { руб. }\end{array}$ & 0,02 & 0,087 & $4,4 \mathrm{p}$. \\
\hline
\end{tabular}

Источник: составлено авторами на основе [5]

В настоящее время, для прогноза социально-инженерного развития территории в качестве критериев принимаются показатели численности населения, количество сельскохозяйственных предприятий, площади используемых земель и посевов. Факторы социально-инженерной инфраструктуры оцениваются с учетом имеющихся ресурсов и участия в финансировании программ федерального и регионального значения.

При этом фактическое состояние и достигнутый уровень социальноинженерного обустройства территории не анализируются в должной мере. Параметры (стандарты) социально-инженерной системы определенной территории не устанавливаются в конкретных условиях. Субъекты территории власть, бизнес и население - остаются замкнутыми, изолированными друг от друга [6]. Управленческое консультирование является одним из барьеров повышения конкурентоспособности в развитии регионов (рис. 1).

Совершенствование взаимоотношений «власть-бизнес-население» для привлечения инвестиций в экономику регулируется Федеральным Законом «О государственно-частном партнерстве» и основывается на объединении ресурсов и распределении рисков публичного и частного партнеров в соответствии с соглашением и проектом, планируемом для реализации. Требует разработки нормативно-правовых актов субъектов РФ и проведения совместного конкурса двумя и более публичными партнерами. Частный партнер обладает сравнительным преимуществом в использовании средств бюджета для реализации соглашения на условиях возвратности, платности и срочности [7]. Так, в сфере гидротехнического строительства распространение получило компенсирование части произведенных расходов инвестора на реконструкцию и строительство мелиоративных объектов и отдельно расположенных гидротехнических сооружений в рамках региональных программ развития сельского хозяйства. Вместе с тем, возникают сложности с несоответствием требований к нормам проектирования, принятым ранее в отраслевых нормативно-технических документах (имеют рекомендательный характер) и утвержденных Постановлением Правительства РФ от 16.02.2008 №87 «О составе разделов проектной документации и требованиях к их содержанию» (ред. от 17.09.2018) [8]. 


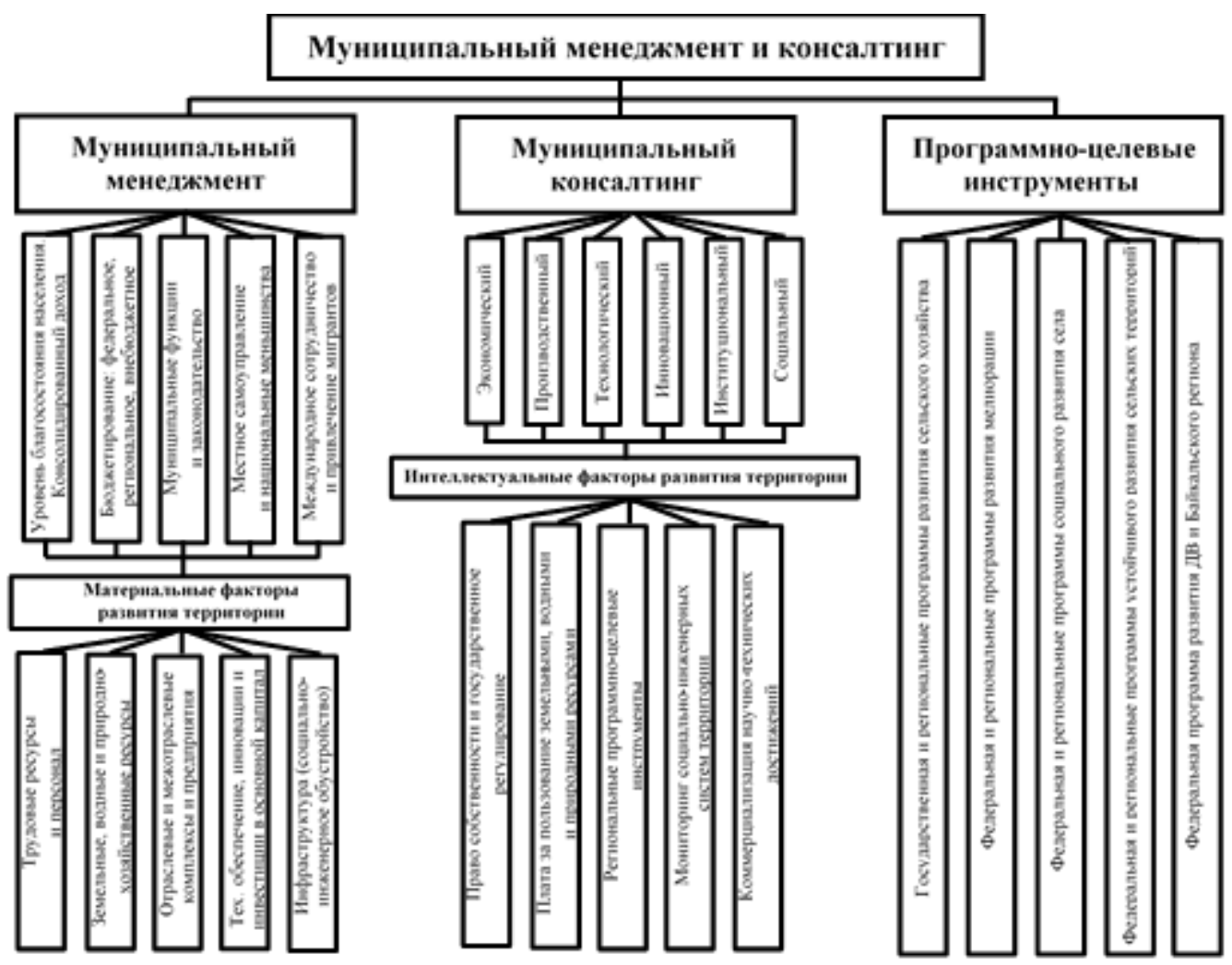

Puc. 1. Организационная модель управленческого консультирования социально-инженерных систем

Источник: составлено авторами на основе [6]

Не соответствуют требованиям принятые отраслевые нормы проектирования профилей полевых дорог и примыканий на мелиоративных системах. Формально составляются разделы архитектурных решений, сведения об инженерном оборудовании, о сетях инженерно-технического обеспечения, мероприятиях и технологических решениях, состоящих из подразделов систем электроснабжения, отопления, вентиляции и кондиционирования воздуха, тепловых сетей, связи, газоснабжения и др., которые нецелесообразны для подобных объектов, но требуются для предоставления в электронном виде на государственную экспертизу.

Обеспечение социально-инженерной системы территории в аграрной сфере представлено на рис. 2.

Совокупность финансирования и регулирования социально-инженерной системы рассматривается как фактор инвестиционной привлекательности территории для предприятий, организаций и сельскохозяйственных товаропроизводителей, государственных бюджетных учреждений региона. Для обеспечения социально-инженерной системы выделяется отдельный блок в государственном регулировании по разработке региональных и муниципальных программ её развития для территорий различной направленности: агломераций, индустриально-промышленных, аграрно-индустриальных и производственных рисовых комплексов (кластеров). 
В.С. Носовский и Ар. // Известия АВФУ. Экономика и управление. 3. 2019. 126-140

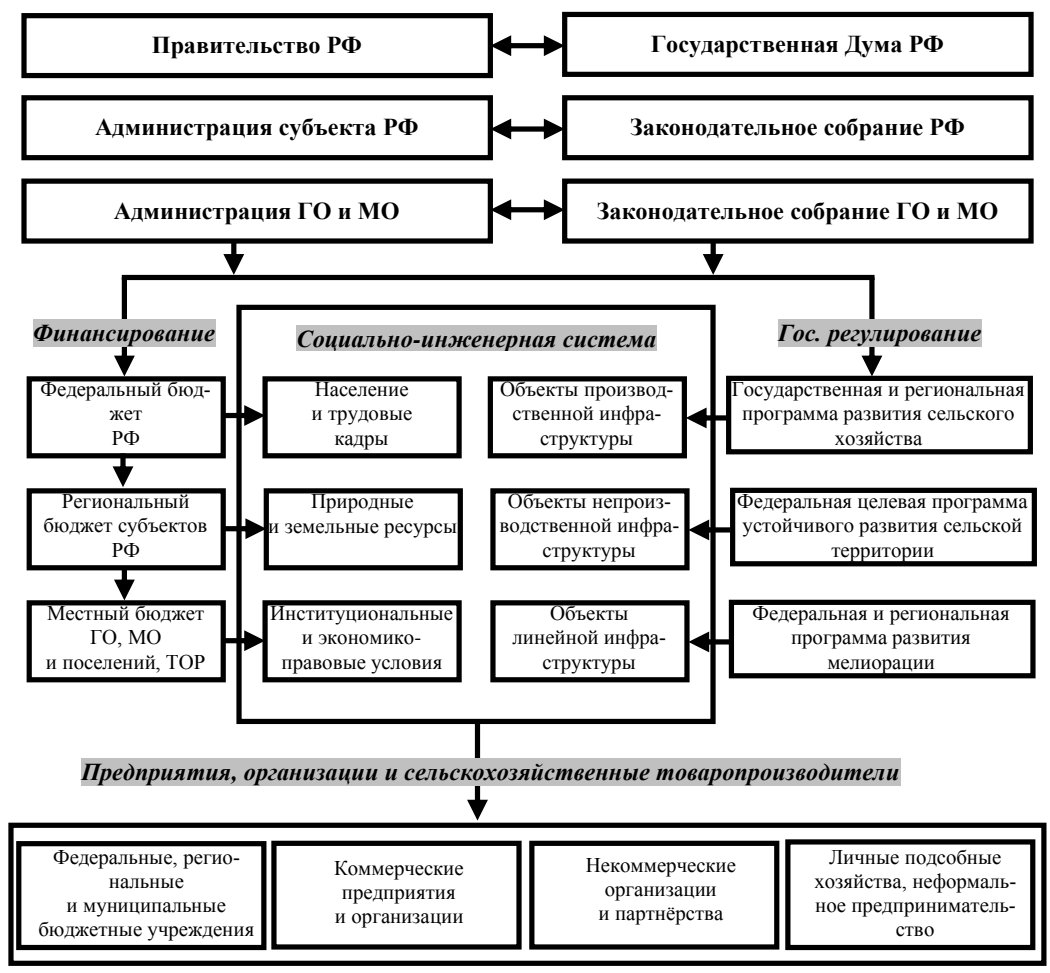

Рuc. 2. Социально-инженерная система и её обеспечение в регионе Источник: составлено авторами на основе [7]

Оценка существенности значений показателей в группах территорий требуется в случае выделения регрессивных тенденций их развития (табл. 4-7).

Таблица 4

Варьирование объемов промышленного производства индустриально-промышленных территорий Приморского края, млн руб.

\begin{tabular}{|c|l|c|c|c|}
\hline № & \multicolumn{1}{|c|}{ Район } & $\boldsymbol{X}_{\max }$ & $\boldsymbol{X}_{\min }$ & $\mathbf{R}\left(\right.$ Отношение $\boldsymbol{X}_{\max } / \boldsymbol{X}_{\min }$ ) \\
\hline 1 & Красноармейский & 3479,8 & 2674,9 & 1,3 \\
\hline 2 & Михайловский & 6021,9 & 3925,8 & 1,53 \\
\hline 3 & Пожарский & 14437,9 & 8538,2 & 1,7 \\
\hline 4 & Спасский & 6720,8 & 4785,3 & 1,4 \\
\hline 5 & Тернейский & 6556,9 & 4715,1 & 1,4 \\
\hline 6 & Хасанский & 2699,9 & 1001,4 & 2,7 \\
\hline 7 & Лазовский & 771,2 & 124,3 & 6,2 \\
\hline Итого: & $\mathbf{4 0 6 8 7 , 5}$ & $\mathbf{2 5 7 6 5 , 0}$ & $\mathbf{1 , 5 8}$ \\
\hline В среднем: & $\mathbf{5 8 1 2 , 5}$ & $\mathbf{3 6 8 0 , 7}$ & $\mathbf{1 , 5 8}$ \\
\hline
\end{tabular}

Источник: составлено авторами 
В.С. Носовский и мр. // Известия АВФУ. Экономика и управление. 3. 2019. 126-140

Таблица 5

Варьирование объемов сельскохозяйственного производства аграрно-индустриальных территорий Приморского края, млн руб.

\begin{tabular}{|c|c|c|c|c|}
\hline № & Район & $X_{\max }$ & $X_{\min }$ & $\mathbf{R}$ (Отношение $\left.X_{\max } / X_{\min }\right)$ \\
\hline 1 & Анучинский & 1111,7 & 835,2 & 1,3 \\
\hline 2 & Дальнереченский & 622,3 & 421,7 & 1,5 \\
\hline 3 & Кавалеровский & 375,0 & 290,3 & 1,3 \\
\hline 4 & Кировский & 1408,9 & 906,2 & 1,5 \\
\hline 5 & Надеждинский & 1665,5 & 1143,7 & 1,5 \\
\hline 6 & Октябрьский & 2740,8 & 2168,3 & 1,7 \\
\hline 7 & Ольгинский & 323,4 & 261,6 & 1,2 \\
\hline 8 & Партизанский & 1187,1 & 815,4 & 1,5 \\
\hline 9 & Пограничный & 1159,2 & 532,0 & 2,2 \\
\hline 10 & Ханкайский & 2588,3 & 1193,1 & 2,2 \\
\hline 11 & Хорольский & 2910,5 & 1658,0 & 1,7 \\
\hline 12 & Черниговский & 1479,6 & 847,9 & 1,7 \\
\hline 13 & Чугуевский & 700,1 & 522,9 & 1,3 \\
\hline 14 & Шкотовский & 547,2 & 452,5 & 1,2 \\
\hline 15 & Яковлевский & 504,1 & 360,9 & 1,4 \\
\hline \multicolumn{2}{|c|}{ Итого: } & 20323,7 & 11380,7 & 1,8 \\
\hline \multicolumn{2}{|c|}{ В среднем } & 1354,9 & 758,7 & 1,8 \\
\hline
\end{tabular}

Источник: составлено авторами

Таблица 6

Варьирование объемов сельскохозяйственного производства рисового комплекса (кластера), млн руб.

\begin{tabular}{|c|l|c|c|c|}
\hline \multicolumn{1}{|c|}{ Район } & \multicolumn{1}{|c|}{$\boldsymbol{X}_{\max }$} & $\boldsymbol{X}_{\min }$ & $\mathbf{R}\left(\right.$ Отношение $\left.\boldsymbol{X}_{\max } / \boldsymbol{X}_{\min }\right)$ \\
\hline 1 & Анучинский & 1111,7 & 835,2 & 1,3 \\
\hline 2 & Спасский & 3559,8 & 1380,2 & 2,6 \\
\hline 3 & Ханкайский & 2588,3 & 1193,1 & 2,2 \\
\hline 5 & Хорольский & 2910,5 & 1658,0 & 1,7 \\
\hline Итого: & Черниговский & 1479,6 & 847,9 & 1,7 \\
\hline В среднем & $\mathbf{1 1 6 4 9 , 9}$ & $\mathbf{5 9 1 4 , 4}$ & $\mathbf{2 , 0}$ \\
\hline
\end{tabular}

Источник: составлено авторами 
Варьирование объемов промышленного производства

\begin{tabular}{|c|l|c|c|c|}
\hline \multicolumn{5}{|c|}{ агломераций Приморского края, млн руб. } \\
\hline № & \multicolumn{1}{|c|}{ Район } & $\boldsymbol{X}_{\max }$ & $\boldsymbol{X}_{\min }$ & $\mathbf{R}\left(\right.$ Отношение $\boldsymbol{X}_{\max } / \boldsymbol{X}_{\min }$ ) \\
\hline 1 & Арсеньев & 24485,0 & 14104,9 & 1,74 \\
\hline 2 & Артем & 11960,0 & 10865,3 & 1,1 \\
\hline 3 & Большой Камень & $7244,4^{*}$ & $7129,9^{* *}$ & 1,02 \\
\hline 4 & Владивосток & 125976,2 & 80773,6 & 1,56 \\
\hline 5 & Дальнегорск & 7334,1 & 4388,0 & 1,67 \\
\hline 6 & Дальнереченск & 785,9 & 477,3 & 1,65 \\
\hline 7 & Лесозаводск & 2528,3 & 1518,3 & 1,67 \\
\hline 8 & Находка & 14403,3 & 8647,9 & 1,66 \\
\hline 9 & Партизанск & 2972,8 & 2217,4 & 1,34 \\
\hline 10 & Спасск-Дальний & 1912,3 & 1203,3 & 1,59 \\
\hline 11 & Уссурийск & 26040,1 & 17956,5 & 1,45 \\
\hline 12 & Фокино & $1460,8 * *$ & $328,3 *$ & 4,4 \\
\hline Итого: & $\mathbf{2 2 7} \mathbf{1 0 3 , 2}$ & $\mathbf{1 4 9} \mathbf{6 1 0 , 7}$ & $\mathbf{1 , 5 2}$ \\
\hline В среднем & $\mathbf{1 8 9 2 5 , 3}$ & $\mathbf{1 2 ~ 4 6 7 , 6}$ & \multicolumn{2}{c|}{} \\
\hline
\end{tabular}

Примечание: *-2015 г., **-2016 г.

Источник: составлено авторами

В отдельных агломерациях варьирование объемов промышленного производства (Арсеньев, Дальнегорск, Дальнереченск, Находка, Фокино) достигает 1,7-4,4, индустриально-промышленных районах (Пожарский, Хасанский, Лазовский) - 1,7-6,2. Объемы сельского хозяйства аграрно-индустриальных районов (Октябрьский, Пограничный, Хасанский) колеблются от 1,7 до 2,2, производственных рисовых комплексов (Хорольский, Черниговский, Ханкайский, Спасский) - от 1,7 до 2,6.

Максимальные значения нередко были достигнуты в ранние годы, а минимальные - в последующие периоды. Такова деформация воспроизводственных процессов. Так, промышленное производство в Приморском крае возросло с минимума в 2012 г. (191,9 млрд руб.) до максимума в 2014 г. (254,7 млрд руб.) на 132,7\%. Далее оно сократилось в 2016 г. (до 235,1 млрд руб.) или 92,3\% (табл. 8).

Таблица 8

Варьирование объемов промышленного производства и сельского хозяйства Приморского края, млн руб.

\begin{tabular}{|c|l|c|c|c|}
\hline \multirow{2}{*}{ № } & \multicolumn{1}{|c|}{ Наименование территорий } & $\boldsymbol{X}_{\max }$ & $\boldsymbol{X}_{\min }$ & $\begin{array}{c}\mathbf{R}(\text { (Отношение } \\
\left.\boldsymbol{X}_{\max } / \boldsymbol{X}_{\min }\right)\end{array}$ \\
\hline 1 & Городские округа* & 18925,3 & 12467,6 & 1,5 \\
\hline 2 & Индустриально-промышленные районы* & 5812,5 & 3680,7 & 1,6 \\
\hline 3 & Аграрно-индустриальные районы** & 1354,9 & 758,7 & 1,8 \\
\hline 4 & Производственные рисовые комплексы** & 2330,0 & 1182,9 & 2,0 \\
\hline $\mathbf{5}$ & Приморский край, всего & $\mathbf{2 9 7 0 7 2 , 6}$ & $\mathbf{2 1 9 7 5 7 , 5}$ & $\mathbf{1 , 3 5}$ \\
\hline Промышленное производство & $\mathbf{2 5 4 7 0 5 , 2}$ & $\mathbf{1 9 1 9 0 8 , 0}$ & $\mathbf{1 , 3}$ \\
\hline Сельское хозяйство & $\mathbf{4 2 ~ 3 6 7 , 4}$ & $\mathbf{2 7 ~ 8 4 9 , 5}$ & $\mathbf{1 , 5}$ \\
\hline
\end{tabular}

Примечание: *- промышленность, **-сельское хозяйство

Источник: составлено авторами

Сельское хозяйство развивается более динамично: с 27,8 млрд руб. (2012 г.) до 42,4 млрд руб. (2016 г.). Рост составил $152,1 \%$. 
Известно, что мелиоративно-водохозяйственный комплекс является очень капиталоемким. С одной стороны, он обеспечивает продовольственную доктрину, а с другой - национальную безопасность и охрану окружающей среды для населения. Не может функционировать без участия государственночастного предпринимательства на сложных объектах земельных участков и гидротехнических сооружений мелиоративных систем сельскохозяйственного назначения.

Условное разделение сооружений мелиоративных систем на межхозяйственную сеть (федеральной собственности) и внутрихозяйственную (третьих лиц) приводит к нарушению деятельности (дисфункции) и целостности функционирования объекта. Собственность третьих лиц на внутрихозяйственную сеть неотделима от земельных участков, предназначена для их обслуживания и должна следовать судьбе главной вещи (земле) в соответствии со статьей 135 ГК РФ. Поэтому внутрихозяйственная сеть должна принадлежать собственнику земли или государственно-частной управляющей компании.

Коэффициент существенности возможностей $\left(\mathrm{K}_{\mathrm{c}}\right)$ развития предпринимательства основан на отношении варьирования максимальных и минимальных значений к среднему консолидированного дохода и объемов ведущего производства (индустриально-промышленного, аграрно-индустриального и др.) на территории. Определяется по формуле:

$$
K_{e}=\frac{V_{d}}{V_{p}},
$$

где $V_{d}$ - вариация консолидированных доходов;

$V_{p}$ - вариация объемов ведущего производства.

При коэффициенте существенности 1,0 и более будут задействованы зависимости доходов территории от роста экономики производства, информационных технологий, платных услуг населению, использования и охраны природных ресурсов. Предлагается следующая градация коэффициента существенности возможностей развития:

$\mathrm{K}_{\varepsilon}$ более 1,0 - благоприятное;

$\mathrm{K}_{\varepsilon}$ от 0,5 до $1,0-$ позитивное;

$\mathrm{K}_{\varepsilon}$ менее 0,5 - негативное.

В настоящее время коэффициент существенности развития предпринимательства сельских территорий составляет в основном ниже 0,5 . В сельской местности практически отсутствуют существенность влияния ведущих отраслей производства на формирование доходов территории и зависимости экономики от изменения институционального предпринимательства.

Развитие сельской территории производится административными методами в рамках федеральных и региональных программ с крайне недостаточным финансированием. Крупные производства, малые и средние предприятия, индивидуальные предприниматели в условиях рыночных отношений не мотивированы на инвестиции в социальные проекты и стандарты территории. Как видно, продолжается оптимизация численности работников в малых предприятиях и сокращение замещенных рабочих мест индивидуальных предпринимателей. Система налогообложения и формирования доходов территории полностью зависит от трудовой занятости и трудовой емкости (численности) населения, а также институциональных условий регистрации юридических лиц вне зависимости от места основного производства и перераспределения налогооб- 
лагаемой базы прибыли в крупные города и агломерации. Помимо объективных факторов распределения капиталов с разным органическим строением основных фондов, в отраслях производства назрели изменения институционального предпринимательства в развитии территории.

В результате установлено, что варьирование консолидированных доходов (отношение максимальных значений к минимальным) составило в среднем для агломераций - 1,29 , индустриально-промышленных районов - 1,31, аграрно-индустриальных - 1,36, производственного рисового комплекса (кластера) 1,26 (табл. 9-15).

Таблица 9

Варьирование консолидированных доходов Агломераций Приморского края, млн руб.

\begin{tabular}{|c|l|c|c|c|}
\hline № & \multicolumn{1}{|c|}{ Район } & $\boldsymbol{X}_{\max }$ & $\boldsymbol{X}_{\min }$ & $\mathbf{R}\left(\right.$ Отношение $\left.\boldsymbol{X}_{\max } / \boldsymbol{X}_{\min }\right)$ \\
\hline 1 & Арсеньев & 1282 & 848 & 1,51 \\
\hline 2 & Артем & 2330 & 2200 & 1,06 \\
\hline 3 & Большой Камень & $1174^{*}$ & $1035^{*}$ & 1,13 \\
\hline 4 & Владивосток & 14894 & 10901 & 1,37 \\
\hline 5 & Дальнегорск & 942 & 885 & 1,06 \\
\hline 6 & Дальнереченск & 549 & 487 & 1,36 \\
\hline 7 & Лесозаводск & 865 & 638 & 1,31 \\
\hline 8 & Находка & 3538 & 2708 & 1,23 \\
\hline 9 & Партизанск & 863 & 704 & 1,41 \\
\hline 10 & Спасск-Дальний & 882 & 624 & 1,29 \\
\hline 11 & Уссурийск & 3863 & 2997 & 1,07 \\
\hline 12 & Фокино & $924 * *$ & $862^{*}$ & $\mathbf{1 , 2 9}$ \\
\hline \multicolumn{2}{|l|}{ Втого: } & $\mathbf{3 2 ~ 1 0 6}$ & $\mathbf{2 4 8 8 9}$ & $\mathbf{1 , 2 9}$ \\
\hline
\end{tabular}

Примечание: *-2016 г., **-2015 г.

Источник: составлено авторами

Таблица 10

Варьирование консолидированных доходов индустриально-промышленных территорий Приморского края, млн руб.

\begin{tabular}{|l|l|c|c|c|}
\hline \multicolumn{1}{|c|}{ № } & \multicolumn{1}{|c|}{ Район } & $\boldsymbol{X}_{\max }$ & $\boldsymbol{X}_{\min }$ & $\begin{array}{c}\mathbf{R}(\text { Отношение } \\
\left.\boldsymbol{X}_{\max } / \boldsymbol{X}_{\min }\right)\end{array}$ \\
\hline 1 & Красноармейский & 587 & 368 & 1,6 \\
\hline 2 & Лазовский & 335 & 220 & 1,3 \\
\hline 3 & Михайловский & 618 & 474 & 1,12 \\
\hline 4 & Пожарский & 514 & 457 & 1,11 \\
\hline 5 & Спасский & 516 & 465 & 1,57 \\
\hline 6 & Тернейский & 379 & 241 & $\mathbf{1 , 3 1}$ \\
\hline 7 & Хасанский & 548 & 436 & $\mathbf{1 , 3 1}$ \\
\hline Итого: & $\mathbf{3 4 9 7}$ & $\mathbf{2 6 6 1}$ & $\mathbf{3 8 0 , 1}$ & \\
\hline В среднем: & $\mathbf{4 9 9 , 6}$ & & \\
\hline
\end{tabular}

Источник: составлено авторами

Таблица 11

Варьирование консолидированных доходов аграрно-индустриальных территорий Приморского края, млн руб.

\begin{tabular}{|c|l|c|c|c|}
\hline № & \multicolumn{1}{|c|}{ Район } & $\boldsymbol{X}_{\max }$ & $\boldsymbol{X}_{\min }$ & $\mathbf{R}$ (Отношение $\boldsymbol{X}_{\max } / \boldsymbol{X}_{\min }$ ) \\
\hline 1 & Анучинский & 313 & 239 & 1,31 \\
\hline 2 & Дальнереченский & 331 & 225 & 1,47 \\
\hline 3 & Кавалеровский & 472 & 324 & 1,46 \\
\hline
\end{tabular}




\begin{tabular}{|c|c|c|c|c|}
\hline 4 & Кировский & 386 & 290 & 1,33 \\
\hline 5 & Надеждинский & 754 & 543 & 1,39 \\
\hline 6 & Октябрьский & 607 & 423 & 1,43 \\
\hline 7 & Ольгинский & 323 & 198 & 1,63 \\
\hline 8 & Партизанский & 799 & 665 & 1,2 \\
\hline 9 & Пограничный & 397 & 294 & 1,35 \\
\hline 10 & Ханкайский & 493 & 341 & 1,45 \\
\hline 11 & Хорольский & 574 & 439 & 1,31 \\
\hline 12 & Черниговский & 696 & 571 & 1,22 \\
\hline 13 & Чугуевский & 644 & 430 & 1,5 \\
\hline 14 & Шкотовский & 483 & 337 & 1,43 \\
\hline 15 & Яковлевский & 315 & 279 & 1,13 \\
\hline \multicolumn{2}{|c|}{ Иmого: } & 7587 & 5595 & 1,36 \\
\hline \multicolumn{2}{|c|}{ В среднем: } & 505,8 & 373 & 1,36 \\
\hline
\end{tabular}

Источник: составлено авторами

Варьирование консолидированных доходов

Таблица 12

производственного рисового комплекса (кластера) Приморского края, млн руб.

\begin{tabular}{|l|l|c|c|c|}
\hline \multicolumn{1}{|c|}{ № } & \multicolumn{1}{|c|}{ Район } & $\boldsymbol{X}_{\max }$ & $\boldsymbol{X}_{\min }$ & $\mathbf{R}\left(\right.$ Отношение $\left.\boldsymbol{X}_{\max } / \boldsymbol{X}_{\min }\right)$ \\
\hline 1 & Анучинский & 313 & 239 & 1,31 \\
\hline 2 & Спасский & 516 & 465 & 1,12 \\
\hline 3 & Ханкайский & 493 & 341 & 1,45 \\
\hline 4 & Хорольский & 574 & 439 & 1,31 \\
\hline Итого: & Черниговский & 696 & 571 & 1,22 \\
\hline \multicolumn{2}{|l|}{ Вреднем: } & $\mathbf{2 5 9 2}$ & $\mathbf{2 0 5 5}$ & $\mathbf{1 , 2 6}$ \\
\hline
\end{tabular}

Источник: составлено авторами

Таблицุа 13

Варьирование консолидированных доходов Территорий Приморского края

\begin{tabular}{|c|l|c|c|c|}
\hline \multirow{2}{*}{ № } & \multicolumn{1}{|c|}{ Наименование территорий } & $\boldsymbol{X}_{\max }$ & $\boldsymbol{X}_{\min }$ & $\begin{array}{c}\mathbf{R}(\text { Отношение } \\
\boldsymbol{X}_{\max } / \boldsymbol{X}_{\min }\end{array}$ \\
\hline 1 & Городские округа & 2675,5 & 2074,1 & 1,29 \\
\hline 2 & Индустриально-промышленные районы & 499,6 & 380,1 & 1,31 \\
\hline 3 & Аграрно-индустриальные районы & 505,8 & 373,0 & 1,36 \\
\hline 4 & Производственные рисовые комплексы & 518,4 & 411 & 1,26 \\
\hline
\end{tabular}

Источник: составлено авторами

Таблица 14

Уровень существенности возможнностей развития территорий Приморского края

\begin{tabular}{|c|l|c|c|c|}
\hline \multirow{2}{*}{$\mathrm{n}$} & \multicolumn{1}{|c|}{ Наименование территорий } & $\begin{array}{c}V_{d} \text { (вариа- } \\
\text { ция дохо- } \\
\text { дов) }\end{array}$ & $\begin{array}{c}\boldsymbol{V}_{p} \text { (вариация } \\
\text { производства) }\end{array}$ & $\begin{array}{c}\boldsymbol{K}_{\boldsymbol{c}} \text { (коэффициент } \\
\text { существенности) }\end{array}$ \\
\hline 1 & Городские округа & 0,29 & 0,5 & 0,58 \\
\hline 2 & Индустриально-промышленные районы & 0,31 & 0,6 & 0,52 \\
\hline 3 & Аграрно-индустриальные районы & 0,36 & 0,8 & 0,45 \\
\hline 4 & Производственные рисовые комплексы & 0,26 & 1,0 & 0,26 \\
\hline
\end{tabular}

Источник: составлено авторами 
Таблицуа 15

Распределение по уровню существенности возможностей развития территорий Приморского края

\begin{tabular}{|c|l|c|c|c|c|}
\hline \multirow{2}{*}{ № } & \multirow{2}{*}{ Наименование территорий } & \multicolumn{2}{|c|}{$\begin{array}{c}\text { Коэффициент существенности } \\
\text { возможностей развития }\end{array}$} & \multirow{2}{*}{$\begin{array}{c}\text { Итого (в } \\
\text { среднем) }\end{array}$} \\
\cline { 3 - 5 } & & $\mathbf{< , 5}$ & $\mathbf{0 , 5 1 - 1 , 0}$ & $\mathbf{1 , 0 1}$ & 0,58 \\
\hline 1 & Городские округа & - & 12 & - & 0,52 \\
\hline 2 & Индустриально-промышленные районы & - & 7 & - & 0,45 \\
\hline 3 & Аграрно-индустриальные районы & 15 & - & - & 0,26 \\
\hline 4 & Производственные рисовые комплексы & 5 & - & - & - \\
\hline
\end{tabular}

Источник: составлено авторами

Уровень существенности возможностей развития территории (как отношение вариации доходов к вариации объемов производства) наиболее высокий (позитивный) наблюдается в городских округах - 0,58 и индустриальнопромышленных районах - 0,52; низкий (негативный) в аграрноиндустриальных территориях - 0,45 и производственных рисовых комплексах $-0,26$ (табл. 10).

В среднем 19 агломераций и индустриально-промышленных районов или $55 \%$ муниципальных образований края имеют позитивный уровень развития территории, а остальные 15 аграрно-индустриальных районов - негативный (табл. 11).

Предлагается организовать межрегиональный водохозяйственный центр предпринимательства (рис.3).

Основное назначение центра: информационное, юридическое и научное сопровождение и оказание услуг, а также инвестирование в проекты реконструкции и строительства, социально-инженерного развития с участием государственно-частного партнерства Приморского края (рис. 4).

Кроме этого, по результатам исследования предлагается разработать инвестиционный инфраструктурный проект комплексного перспективного освоения земель и реконструкции мелиоративных объектов до 2030-2035 гг. и организационный механизм институционального предпринимательства водохозяйственного комплекса аграрной сферы Приморского края.

В завершение, необходимо обосновать уровни существенности развития предпринимательства: негативный - менее 0,5 , позитивный - от 0,5 до 1,0 и благоприятный - более 1,0 , установить субстратные параметры социальноинженерной системы территорий районов края. 


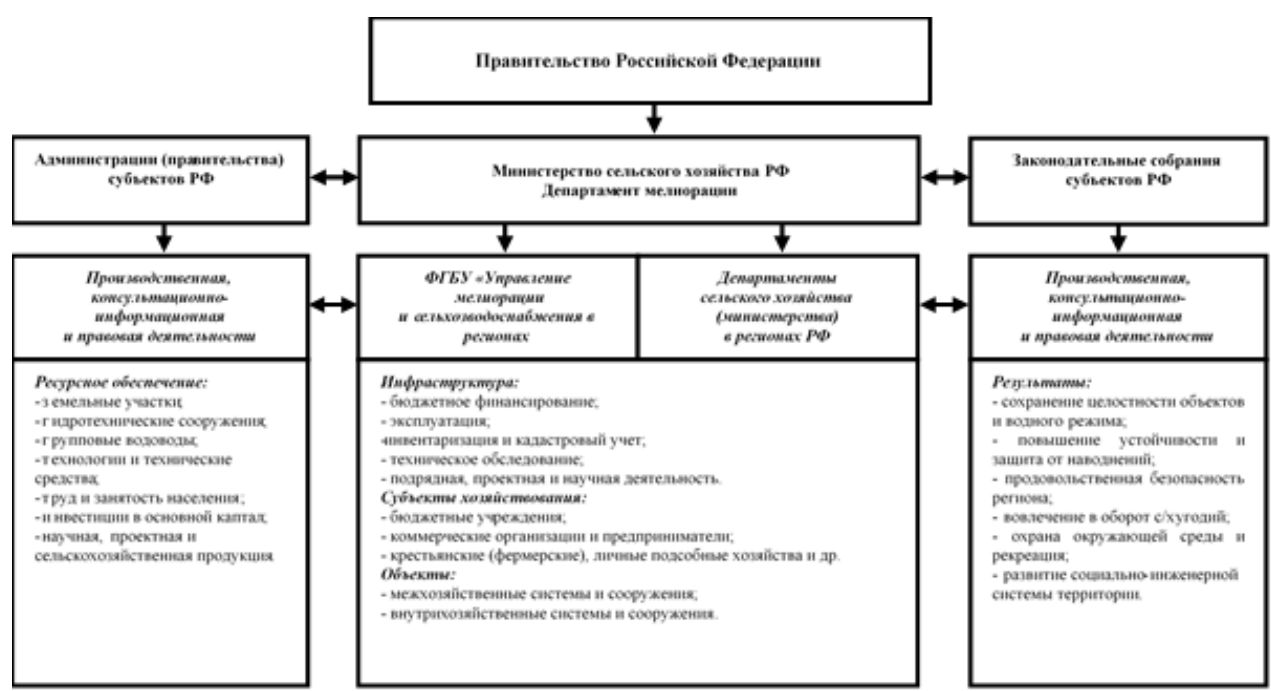

Puc. 3. Структура межрегионального водохозяйственного

Источник: составлено авторами центра предпринимательства

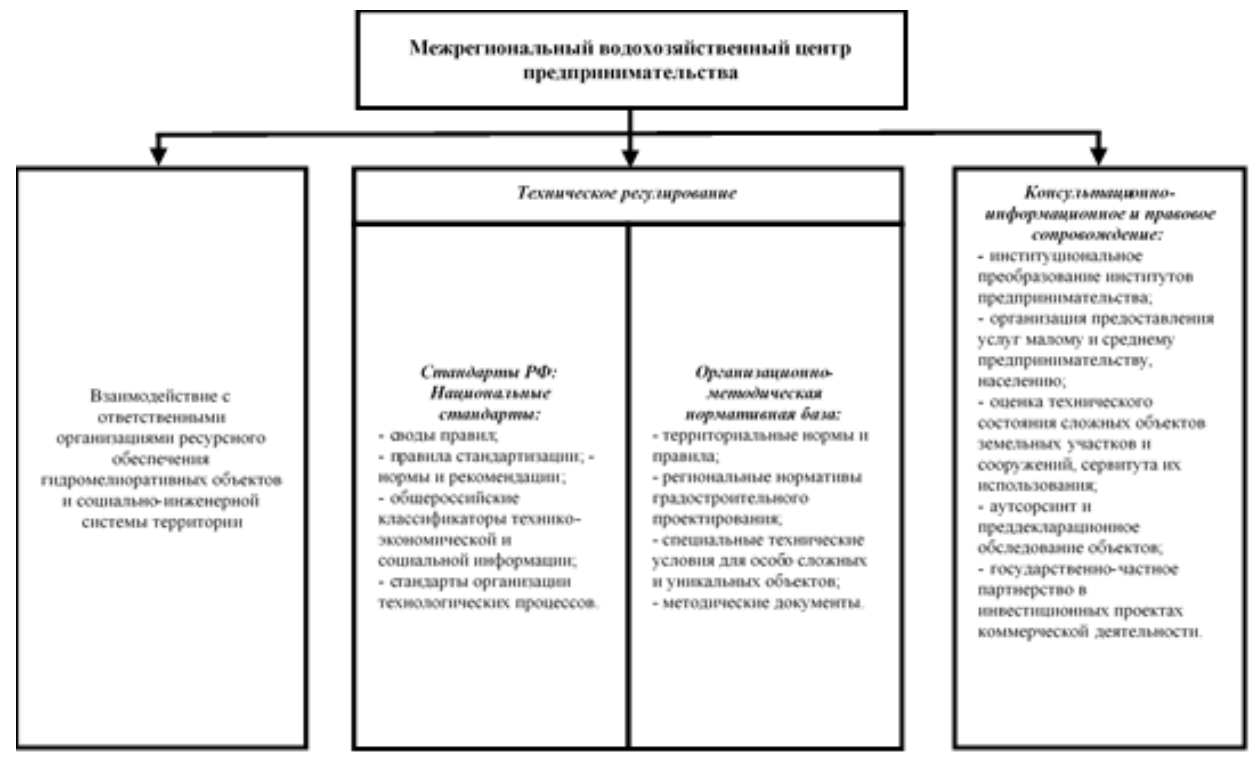

Puc. 4. Механизм функционирования межрегионального водохозяйственного центра предпринимательства

\section{Список источников / References}

1.Маркс К. Теории прибавочной стоимости: (IV том" Капитала"). Москва, гос. изд-во полит. лит-ры, 1954. 477 с. [Marks K. Teorii pribavochnoj stoimosti: (IV tom" Kapitala") [Theories of Surplus Value: (Volume IV of Capital)]. Moscow, Gos. Polit. Literature Publ., 1954. 477 p.]

2. North D.C. The contribution of the new institutional economics to an understanding of the transition problem. - Unu/Wider, 1997, no. 1. 
3. Dimaggio P., Powell W.W. The iron cage revisited: Institutional isomorphism and collective rationality in organizational fields. Organizational Studies: Critical Perspectives. Routledge, 1999, pp. 147-160.

4. Maguire S., Hardy C., Lawrence T.B. Institutional entrepreneurship in emerging fields: HIV/AIDS treatment advocacy in Canada. Academy of management journal, 2004, vol. 47, no 5., pp. 657-679.

5. Виноградов А.В. Институциональная экономика: теория и практика. Минобрнауки РФ. Учебно-метод. пособие. Нижний Новгород: Нижегородский университет, 2012. 12 c. [Vinogradov A.V. Institucional'naya ekonomika: teoriya i praktika [Institutional Economics: Theory and Practice]. Minobrnauki RF. Uchebno-metod. posobie. Nizhnij Novgorod: Nizhegorodskij universitet, 2012. 12 p.]

6. Галлямов Ф.Ф., Борисов К.Б. Муниципальный менеджмент: опыт, проблемы, консультирование: монография. Под науч. ред. д-ра техн. наук В.В. Горчакова, д-ра экон. наук М.В. Терского. Владивосток: ТЦ СР, 2005. 184 c. [Gallyamov F.F., Borisov K.B. Municipal'nyj menedzhment: opyt, problemy, konsul'tirovanie [Municipal management: experience, problems, consulting]: monografiya. Pod nauch. red. d-ra tekhn. nauk V.V. Gor-chakova, d-ra ekon. nauk M.V. Terskogo. Vladivostok: TC SR, 2005. 184 p.]

7. Федеральный закон от 13.07.2015 3224-Ф3 «О государственно-частном партнерстве, муниципально-частном партнерстве в Российской Федерации и внесении изменений в отдельные акты Российской Федерации [Federal`ny`j zakon ot 13.07.2015 3224-FZ «O gosudarstvenno-chastnom partnerstve, municipal no-chastnom partnerstve v Rossijskoj Federacii i vnesenii izmenenij v otdel`ny`e akty` Rossijskoj Federacii [Federal Law of 13.07.2015 3224-Ф3 “On Public-Private Partnership, Municipal-Private Partnership in the Russian Federation and Amendments to Certain Acts of the Russian Federation]]. Available at: http://Base. Garant.ru / 71129190.

8. Постановление Правительства РФ от 16.02.2008 № 87 (ред. от 17.09.2018) «О составе разделов проектной документации и требования к их содержанию» [Postanovlenie Pravitel'stva RF ot 16.02.2008 № 87 (red. ot 17.09.2018) «O sostave razdelov proektnoj dokumentacii i trebova-niya $\mathrm{k}$ ix soderzhaniyu» [Resolution of the Government of the Russian Federation No. 87 dated February 16, 2008 (as amended on 09/17/2018) "On the composition of sections of project documentation and requirements for their content"]]. Available at: http://consultant.ru / document / cons_doc.

\section{Сведения об авторах / About authors}

Носовский Валерий Сергеевич, доктор экономических наук, профессор Дальневосточного федерального университета, первый заместитель генерального директора акционерного общества «Дальневосточный научно-исследовательский институт гидротехники и мелиорации» (АО «ДальНИИГиМ»). 690014 Россия, Владивосток, проспект Красного Знамени, 66.

E-mail: nosovsky@bk.ru

Valeriy S. Nosovskiy, Doctor of Economic Sciences, Professor of the Far Eastern Federal University, First Deputy General Director of the Far Eastern Research Institute of Hydraulic Engineering and Land Reclamation. 66, Krasnogo Znameni Ave., Vladivostok, Russia 690014.E-mail: nosovsky@bk.ru

Приходько Данил Сергеевич, соискатель, Школа экономики и менеджмента, Дальневосточный федеральный университет. 690022 Россия, г. Владивосток, о-в Русский, кампус ДВФУ, корпус G. E-mail:prikhodko_ds@students.dvfu.ru

Danil S. Prikhodko, School of Economics and Management, Far Eastern Federal University. Building G, FEFU campus, Russky Island, Vladivostok, Russia 690922.E-mail: prikhodko_ds@students.dvfu.ru

Султанова Алина Анатольевна, соискатель, Школа экономики и менеджмента, Дальневосточный федеральный университет. 690022 Россия, г. Владивосток, о-в Русский, кампус ДВФУ, корпус G. E-mail: sultanova.aa@dvfu.ru 
В.С. Носовский и мр. // Известия АВФУ. Экономика и управление. 3. 2019. 126-140

Alina A. Sultanova, School of Economics and Management, Far Eastern Federal University. Building G, FEFU campus, Russky Island, Vladivostok, Russia 690922. E-mail: sultanova.aa@dvfu.ru

(C) Носовский В.С., Приходько Д.С., Султанова А.А.

(C) Nosovskiy V.S., Prikhodko D.S., Sultanova A.A.

Адрес сайта в сети интернет: http://jem.dvfu.ru 